\title{
First report of Phyllachora serjaniicola causing tar-spot on Cardiospermum grandiflorum
}

\author{
Jadergudson Pereira ${ }^{1}$, José Luiz Bezerra ${ }^{1}$, Elisandro Ricardo Drechsler-Santos ${ }^{2} \&$ Leonor Costa Maia $^{2}$ \\ ${ }^{1}$ Departamento de Ciências Agrárias e Ambientais, Universidade Estadual de Santa Cruz, 45662-000, Ilhéus, BA, Brazil; \\ ${ }^{2}$ Departamento de Micologia, Universidade Federal de Pernambuco, 50670-420, Recife, PE, Brazil
}

Author for correspondence: Jadergudson Pereira, e-mail: jader@uesc.br

\begin{abstract}
A stromatic tar-spot fungus, found associated with Cardiospermum grandiflorum from the Parque Nacional do Vale do Catimbau (Buíque PE), was collected and identified as Phyllachora serjaniicola. This represents the first report of this fungus on C. grandiflorum. Key words: Phyllachoraceae, Ascomycota, Sapindaceae.

\section{RESUMO}

Primeiro relato de Phyllachora serjaniicola causando mancha-de-piche em Cardiospermum grandiflorum

Um fungo estromático causador de mancha-de-piche, associado a Cardiospermum grandiflorum no Parque Nacional do Vale do Catimbau (Buíque PE), foi coletado e identificado como Phyllachora serjaniicola. Este é o primeiro relato deste fungo em C. grandiflorum.
\end{abstract}

Palavras-chave: Phyllachoraceae, Ascomycota, Sapindaceae.

Species of Cardiospermum (Sapindaceae) occur naturally in tropical Africa, Asia and America. Some species in this genus have spread to most tropical and subtropical regions of the world, either as ornamentals or accidentally, becoming weeds (Kissman \& Groth, 1995). Cardiospermum grandiflorum Sw. (balloon vine, heart seed; local name: ensacadinha) is considered a noxious weed in Australia (Carroll et al., 2005) and in South Africa (Olckers, 2004). It is also known to have some medicinal properties (Burkill, 2000). In South Africa there are reports of ongoing research on the rust fungus Puccinia arechavaletae as a potential biological control agent for C. grandiflorum (Olckers, 2004). No other fungal pathogen has been evaluated for that purpose and there is no published result of intensive surveys of fungi pathogenic to C. grandiflorum.

In April 2007, leaves of C. grandiflorum showing typical tar-spot symptoms and bearing amphigenous black stromata (Figures 1 and 2) were collected in an area of dry scrubland (Caatinga) in the Parque Nacional do Vale do Catimbau, municipality of Buíque, State of Pernambuco, Brazil ( $8^{\circ} 34^{\prime} 56^{\prime \prime}$ S and $37^{\circ} 14^{\prime} 26^{\prime \prime} \mathrm{W}$; $787 \mathrm{~m}$ alt.).

The fungus associated with the disease had the following morphology: stromata black, carbonaceous, subcircular to irregular, amphigenous, slightly raised, subglobose stromata, $0.5-3 \mathrm{~mm}$ diam; perithecia black, immersed in the palisade layer, clypeate, ostiolate, 200-250 $\mu \mathrm{m}$ diam. (Figure 1); ostiole minute, flattened, periphysate; perithecial walls, $12-22 \mu \mathrm{m}$ thick, two-three layered of flattened brown cells; asci unitunicate, thinwalled, cylindrical-clavate, 8 -spored, $60-70 \times 11-17 \mu \mathrm{m}$; paraphyses colorless, filiform, branched, abundant, persistent; ascospores aseptate, smooth, uniseriate, ellipsoid, hyaline, 11-12 x 8-9 $\mu \mathrm{m}$ (Figure 2).

The fungus was identified as Phyllachora serjaniicola (Chardon, 1921). Other Phyllachora species reported in Brazil on plants belonging to the Sapindaceae differ from P. serjaniicola by the following characteristics: P. alamoi Chardon is associated with conspicuous large ( $>1 \mathrm{~cm}$ diam) foliicolous and cauliicolous stromata (Chardon \& Toro, 1934); the ascospores of $P$. duplex Rehm are significantly larger (16-20 x 9-10 $\mu \mathrm{m})$ (Chardon, 1921); P. galavisii Chardon forms conspicuous stromata and has ascospores which are surrounded by a hyaline envelope (Chardon \& Toro, 1934); P. insueta Syd. produces larger and narrower ascospores (13-17 x 5-7.5 $\mu \mathrm{m})$ (Sydow, 1925) and forms pustule-like stromata (Chardon \& Toro, 1934).

A representative specimen of $P$. serjaniicola from $C$. grandiflorum was deposited in the Herbarium Pe. Camille Torrend - URM (BRAZIL: Pernambuco, Buíque, Parque Nacional do Vale do Catimbau, 13.IV.2007, leg. Jad. Pereira, on living leaves of Cardiospermum grandiflorum; URM 78850).

This is the first report of $P$. serjaniicola on $C$. grandiflorum worldwide. This fungus also occurs on other Sapindaceae: Serjania caracasana Willd., S. mexicana Willd., S. paniculata HBK, S. polyphylla Poir. and 


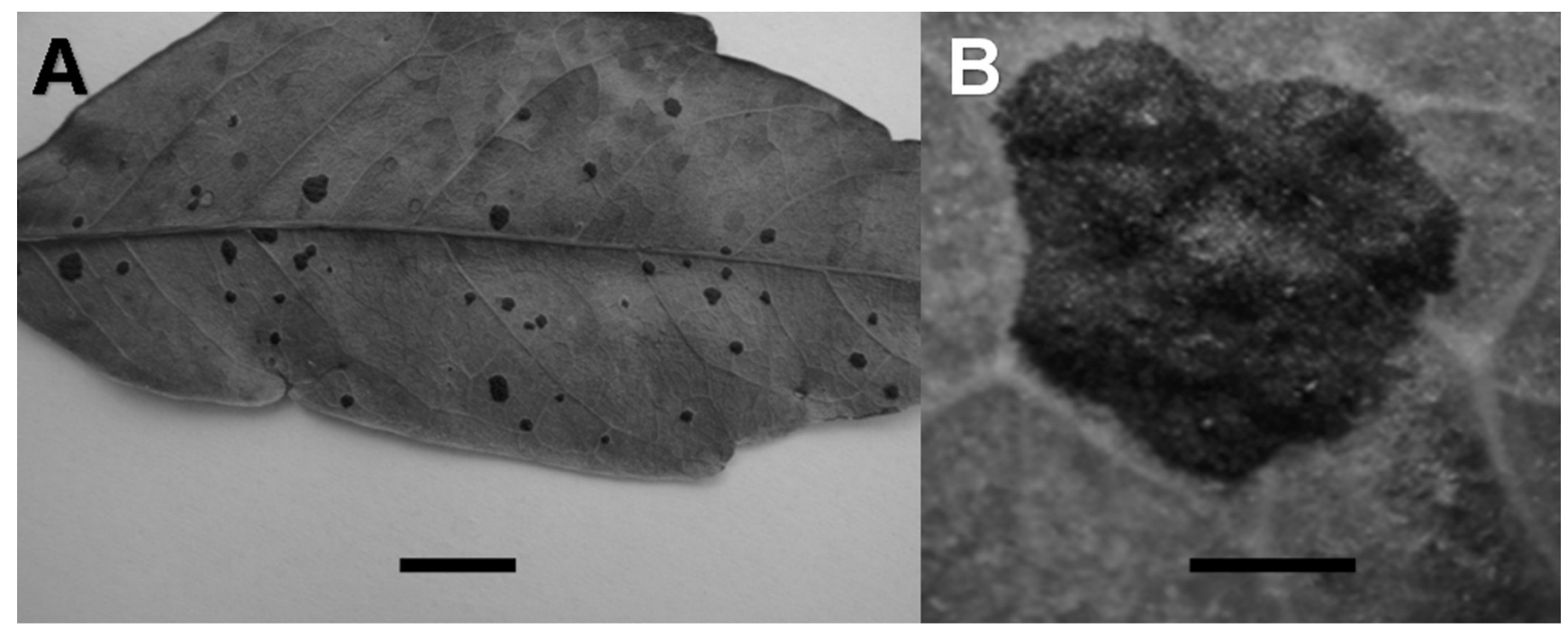

FIGURE 1 - Cardiospermum grandiflorum showing tar-spots. A. Stromata on adaxial leaf surface. B. Close view of a well developed stroma of Phyllachora serjaniicola. Scale bars: A = $5 \mathrm{~mm} ; \mathrm{B}=100 \mu \mathrm{m}$.

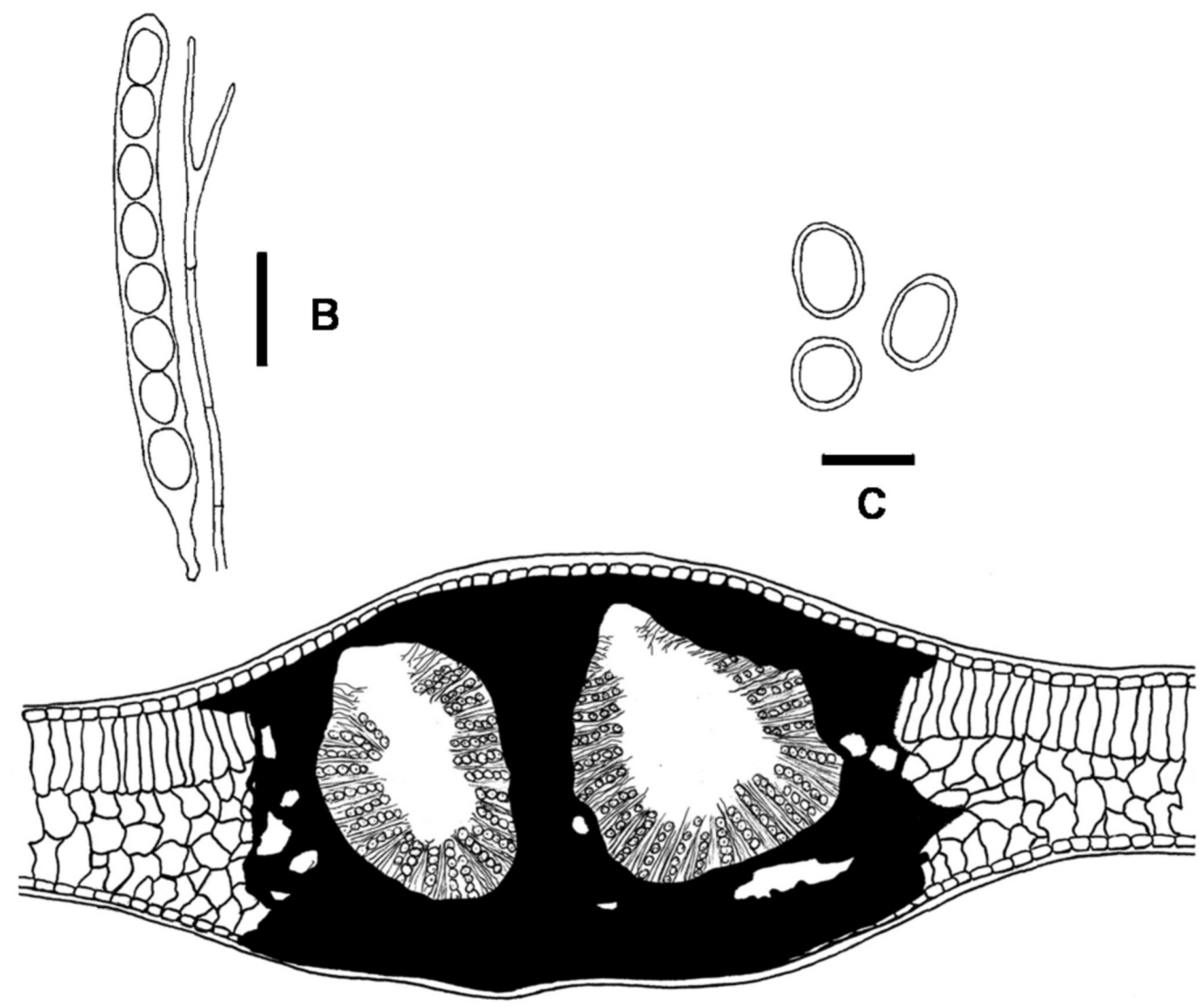

FIGURE 2 - Structures of Phyllachora serjaniicola. A. Section of perithecium. B. Ascus and paraphyses. C. Mature ascospores. Scale bars: $A=200 \mu \mathrm{m} ; \mathrm{B}=20 \mu \mathrm{m} ; \mathrm{C}=10 \mu \mathrm{m}$. 
Serjania sp. (Seaver, 1924; Viégas, 1961). In Brazil, only Meliola mullerii Toro and P. arechavaletae have been previously reported on C. grandiflorum (Mendes et al., 1998). The limited damage caused by $P$. serjaniicola to $C$. grandiflorum observed in the field suggests that this fungus has limited potential to be used as a biocontrol agent in classical programs.

\section{ACKNOWLEDGEMENTS}

The authors thank the Programa de Pesquisa em Biodiversidade Semi-Árido PPBio, Conselho Nacional de Desenvolvimento Científico e Tecnológico - CNPq and Fundação de Amparo à Pesquisa do Estado da Bahia - FAPESB for financial support. Ibama, Parque Nacional do Vale do Catimbau, is also acknowledged for providing permission to make collections in the Park area; Prof. Marcus Alves, Departamento de Botânica, UFPE, is also thanked for identification of the host plant.

\section{REFERENCES}

Burkill HRM (2000) The Useful Plants of West Tropical Africa, vol.5, Kew, UK: Royal Botanic Gardens.
Carroll SP, Mathieson M, Loye JE (2005) Invasion history and ecology of the environmental weed ballon vine, Cardiospermum grandiflorum Swartz, in Australia. Plant Protection Quarterly 20:140-144.

Chardon CE (1921) A contribution to our knowledge of the Pyrenomycetes of Porto Rico. Mycologia 13:279-303.

Chardon CE, Toro RA (1934) Mycological explorations of Venezuela. Monographs of the University of Puerto Rico. Serie B, n. 2.

Kissman KG, Groth D (1995) Plantas infestantes e nocivas, vol. 3. São Paulo SP. BASF.

Mendes MAS, Silva VL, Dianese JC, Ferreira MASV, Santos, CEN, Gomes Neto E, Urben AF, Castro C (1998) Fungos em plantas no Brasil. Brasília DF. Embrapa-SPI, Embrapa-Cenargen.

Olckers T (2004) Targeting emerging weeds for biological control in South Africa: the benefits of halting the spread of alien plants at an early stage of their invasion. South African Journal of Science 100:64-68.

Seaver FJ (1924) The fungous flora of St. Thomas. Mycologia 16:1-17.

Sydow H (1925) Fungi in itinere Costaricensi collecti. Pars prima. Annales Mycologici 23:372.

Viégas AP (1961) Índice de fungos da América do Sul. Campinas, SP, Instituto Agronômico.

TPP 8103 - Received 2 January 2010 - Accepted 25 August 2010 Section Editor: Robert W. Barreto 